\title{
Contribution of secondary education towards economic growth in Ngara District, Tanzania
}

\begin{abstract}
Received 23 October, 2021 Revised 3 December, 2021 Accepted 15 December, 2021 Published 3 December, 2022

The purpose of this study was to examine the contribution of secondary education towards economic growth in Ngara District. The study was guided by three research objectives which are; to identify the contribution of the education achieved in secondary school graduates on economic growth, to assess the relationship between secondary school education and economic growth and the last one was to analyze the challenges that face secondary education leavers in the job market. The study was guided by Human Capital Theory which was developed by Schult and Becker.The research used mixed approach technique which entails qualitative and quantitative. In qualitative, the study analyzed the findings by looking at the physical trends while quantitative, the findings were analyzed using measurements in terms of inferential statistics. From the findings, the results reveal that there is a direct connectivity between school education and practical implementation of the knowledge gained in classrooms. Moreover, the findings established that there is low contribution in education achieved in secondary-bysecondary school leavers which cannot cater for their economic income. The study recommends that the government should device friendly curriculum which is environment friendly. This will help secondary school leavers to translate their education into economic growth activities. Moreover, the secondary school leavers are advised to link what they gained in their course of schooling in order to avoid depending much on their guardians and parents.
\end{abstract}

Keywords: Contribution, secondary school, education, economic, growth, job market.

\section{INTRODUCTION}

The development of any society both socially ,economically, and politically depends on the quality of education, and the quality of education depends on the quality of teachers, students and effective involvement of parents in education (Paschal, and Mkulu, 2020). One of the main intentions in teaching and learning is to bring both professional growth and academic progress in learners that could be able to enhance social and economic progress (Paschal, and Mkulu, 2020). From the above standing point, human beings have been educating each other even before the introduction of formal education because norms and traditions have to be handed down from older generations to young generations for preservations. From ancient times and in the contemporary world, education has become a cornerstone to national economic growth. This entails the stock of skills, competencies, and other productivityenhancing characteristics (World Economic Forum, 2016). Similarly, World Economic Forum argues that human capital has long been considered the most distinctive feature of the economic system in development and productivity growth. In a nutshell, education is a critical component in developing a country's human capital, increasing the efficiency of each worker and helping the development of economies in a given or relevant nation. 
Globally, education has been a key to the economic and social development of the respective countries and impacted individuals' present and future income capacity (Klyachko and Semionova, 2018). In a similar vein, Ngasa (2016) comments that each country worldwide has made purposive efforts to ensure adequate investment in the education sector. This has seen the achievement of sustainable economic growth of that nation. In a nutshell, educational skills not only focus on an individual's highincome generation but also as a source of economic development from personal to country-level. Generally, Education is the key to success. It is an instrument for the economic development of the people and nation because the knowledge and skill obtained from education should contribute to individuals, communities and national economic growth.

Concerning the current Study, Geofrey (2017) argues that a country cannot achieve sustainable economic growth without investing in human capital. Similarly, the study conducted by Klyachko and Semionova (2018) asserted that in both Russian federation as a whole for the federal districts and regions of Russia, there are positive benefits of education with economic growth of Russian regions. The study assumed that graduates enter the labour market and hugely contribute to the economic development of the Russian economy. However, the UK Essays (November 2018) states that Pakistan's economy has grown faster than other low or middle-income countries, but some other countries in South Asia have done far better. The significant reason is the quality of human capital obtained from the education system. In the light of this statement, the investment of human capital results in economic growth. The different world nations have invested much in the education sector to ensure the effective economic development of their people (Akaro and Mkulu, 2020). In the same coin, Melles (2000) argues that in any developing country, included Tanzania, human resources of a nation returned from the education system determine the economic growth of a nation and not only its physical capital or its natural resources that define the character but also step of its economic growth. Furthermore, Paschal and Mkulu, (2020); Geoffrey (2017) comment that education in Tanzania improves the quality of life for the nation and leads to broad social and economic benefits to individuals and the country in general. In light of this perception, Paschal et al. (2020) noted that Tanzania has been investing much in education to have a good return in future economy. The question we can ask ourselves is, is real Tanzanian education contributed to the citizen's economy? Hence, in this regard, the researcher wants to find out the contribution of secondary education towards economic growth in Tanzania to enable people to understand themselves and the world at large. However, some scholars such as Mkulu (2020) claimed that for a country to achieve sustainable economic growth, it must invest in education since education is essential for national economic development. Tanzania is one of the developing countries whose economic growth depends much on the investment in human capital. The output of human capital in education leads to effective economic development. As supported by
Ngasa (2016), Human capital increases the national worker productivity and technology advancement.

\section{Statement of the Problem}

Education is a cornerstone to national development (Mkulu and Paschal, 2020). That means Economic growth depends on education policies in a given country. This study explores the contribution of secondary education towards economic growth in the Ngara district. It is a special low economic growth rate in many developing countries, known as third world countries. Tanzania is one of the developing countries that have notable middle-income households. In some districts of Tanzania Main Land and Zanzibar, there are several problems such as lack of food, insecurity, poverty, malnutrition, and disasters perpetuated by low economic growth in some households (the World Bank Group, 2019). In addition it was reported that the trend of nation economy development in Tanzania was increasing slightly. In that report, it was indicated that the growth of domestic per capital income showed 7.0 and 6.8 in the years 2018 and 2017 respectively. In this scenario the absolute number of poor citizens has not declined. Again, individuals' per capita income is still the same even among form four leavers are graduated in every district of Tanzania including Ngara. Although the form four leaves in Ngara and Tanzania as whole seem not to be job creators as expected (Abayo, 2017). The study assumes that such form four leavers could have utilized their human capital for improving the economic growth. Based on the review that has been made, there is little information that explains the impact of secondary school graduates on economic growth. Therefore, this study anticipates coming up with information describing how secondary education contributes to economic growth in Ngara District.

\section{Purpose of the study}

The current study aimed to examine the contribution of secondary school education towards economic growth in Ngara District - Kagera Region. It is guided by three specific objectives as identified below. The study focused on the following specific objectives.

i. To identify the contributions of secondary school leavers on economic growth in Ngara District.

ii. To examine the relationship between secondary education leavers and economic growth in Ngara District

iii. To analyse the challenges facing the secondary school education system in economic growth in Ngara District.

\section{Significance of the Study}

The findings of this study will contribute to the national policy review, especially on the curriculum content, so that education to be provided may play a more significant role in the economic growth of an individual and the nation. The study will also show the greater importance of investing in education for a good return in the study area and at a national level. In addition, the study will be beneficial to the 
Figure 1: Conceptual Framework

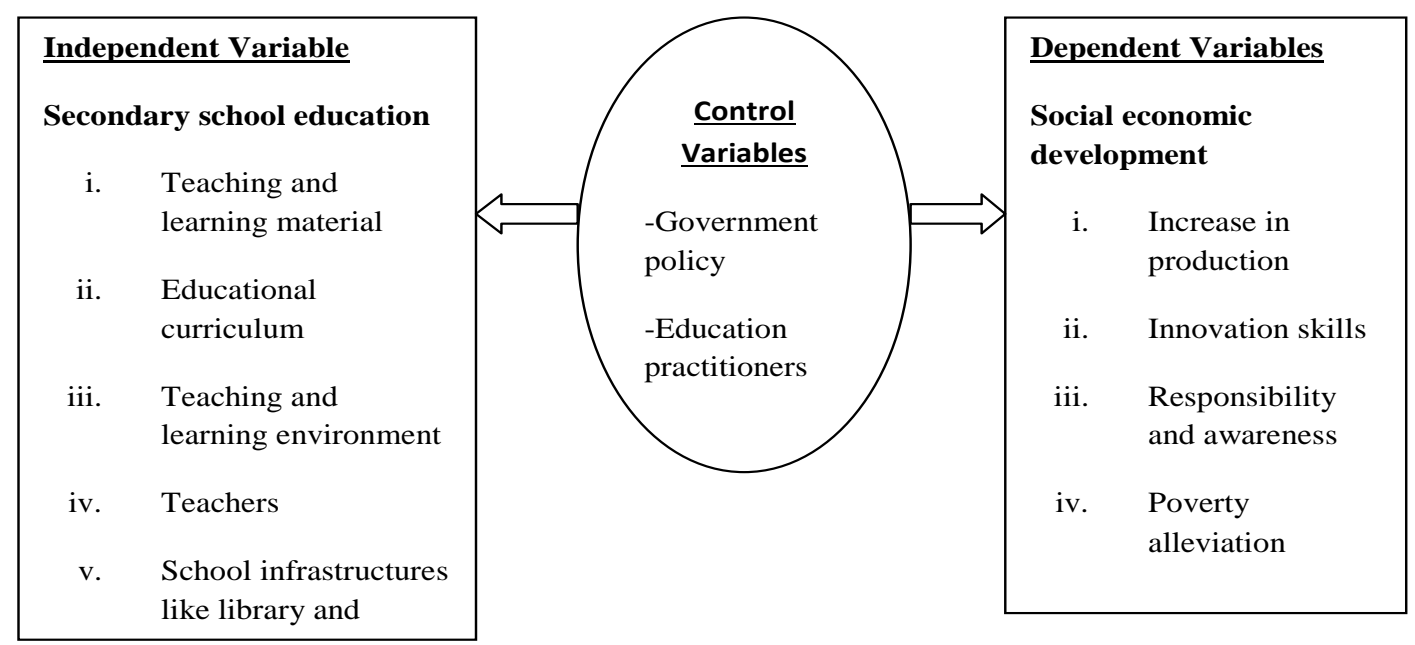

Adopted by Researcher (2021)

education practitioners in Ngara District and the nation at large on the challenges facing the secondary school education system in contributing to national economic growth. The study will also be significant to other researchers interested in carrying out a similar study. The current study will be very crucial to the researcher because she will be able to acquire the master degree furthermore the researcher will gain more knowledge in the process of teaching and learning Besides, the current study will significantly enrich different studies as it adds to the existing literature that has already been undertaken concerning the contribution of education to economic growth.

Education practitioners and government policy act as control variables of the study. The government policy or education practitioners may affect at any status the presence of teaching and learning materials, education curriculum, teachers and school infrastructures like libraries and laboratories (independent variables) which facilitate the provision of education. Secondary school education outcomes include increased production, innovation skills, responsibility awareness, and poverty alleviation (dependent variables). On top of that, the efficiency of results (dependent variables) will also depend on how the government policy is implemented and the participation of education practitioners. When these variables strongly interact, they will produce education that focuses on national economic development, hence reducing problems like poverty, food insecurity, and other disasters(Figure 1).

\section{Literature review}

\section{Theoretical Review}

Theories are knowledge and understandings that guide any study. They are well stipulated guidelines that steer thesis and dissertation writing. In this Study, Human Capital
Theory was show the whole knowledge as per the topic. This theory's proponent is Schultz and Becker in 1960. The main issue behind Schultz and Becker on education is that education is an investment because individuals compare the direct and opportunity costs of education with its future benefits (Melles, 2000). Human capital refers to the capacity of human beings as creative personnel's and productive agents to promote increases in income through the acquisition of skills and the accumulation of knowledge Lameck (2016). Similar, Geofrey (2017) provides that Human Capital Theory refers to the stock of knowledge, skills, habits, social and personality attributes that entail creativity embodied in the ability to perform labor to produce economic value in a nation. In this line, Tanzania seriously needs capital creation, whereby education is hugely and highly recommended.

Education is the apparatus for national development and economic growth since the investment in human capital in the nation leads to economic growth. Therefore, the skills accumulated in secondary education are expected to enhance productivity and the knowledge imparted to generate and stimulate innovation in a country. Human Capital Theory further observes that higher skill and knowledge level in the workforce improves the production capacity and a nation's economy. Geofrey (2017) argues that the contribution of secondary education to national economic development occurs through its ability to increase the productivity of an existing labour force.

The theory of human capital will be helpful in this study since it shows the significance of human capital obtained in education to the economic development of a nation. The government should invest much in education to empower students with skills and knowledge applicable in production since good education leads to reducing poverty and the effective achievement of sustainable national economic growth. Therefore, human Capital Theory is helpful in addressing the economic development plan of a nation since it directly shows how to invest in humans for a 
better return to the country.

\section{Empirical Review}

\section{Contributions of Secondary Education Achieved by Secondary School Graduates on Social Economic Development}

Flora (2019), UNESCO (2017) and Chanksenlian et al. (2020) derived from many scholars, including those who argued that development within a country is not possible in whatever means without giving education to the people. The people, who are consumers, need to see the growth in terms of their income due to education. In addition, Sakmurzaeva (2019), in the Study about the role of education in economic development compared to South Korea and Kyrgyzstan, had a similar idea with other scholars that no country can succeed in sustainable economic growth without an educated human capital. Based on these scholars, education helps people to understand themselves and the world. It improves the quality of their lives and directs individuals and society to broader social benefits. Therefore, education is critical in raising the productivity of people and contributes to technological development.

In India, for instance, Kapur (2020) conducted a study on how the acquisition of secondary education contributes to socio-economic growth in rural and urban areas. The study mainly focussed on the recognition of secondary education in promoting economic growth, the contribution of secondary education in promoting economic growth, and professionalism in promoting economic growth. On the contribution of secondary education toward economic growth, the findings revealed that secondary education had rendered an important contribution in enabling the students to increase their skills and abilities required in promoting economic growth.

Moreover, Misra (2012) conducts an empirical study on the contribution of education to socio-economic growth. The study showed that the data were obtained from secondary sources only. This study will focus on both primary and secondary data collection. The study reviewed various findings of the research on the contribution of education in economic development. The study's findings show that education is the basis of all activities in life and social development. Therefore, the researcher concluded that education should foster economic growth and social development. The study was descriptive in nature which showed that the descriptive analyses of the data were used. Similarly, Grant (2017) comments that "education as a critical component of a country's human capital increases the efficiency of each individual worker and helps economies to move up the value chain beyond manual tasks or simple production processes" (p.2).

Lupeja and Gubo (2016) conducted a study conducted in the Mvomero district in Tanzania on the influence of secondary education in promoting; health awareness, gender awareness and civic awareness. The study assessed whether secondary education brings social and economic transformation. Is this transformation reflected in graduates' livelihood strategies once they graduate and go back to the societies? The study employed a quantitative research approach in the data collection and analysis. However, this study will use both qualitative and quantitative research approaches. The result of the study mentioned above shows that education has a negligible impact in influencing livelihood strategies to the graduates. This shows an existing problem where the secondary education policy of Tanzania shows that the development of socio and economic aspects should be influenced by the education acquired. Therefore, the current study seeks to assess the contribution of secondary education towards the socio-economic development in Ngara district.

Abayo (2017) conducted a study in Kilindi District on the contribution of Ward secondary schools into form four leavers' socio-economic growth. The study involved questionnaires, interviews and focus group discussions on the data collection. The current study will employ questionnaires and interviews in collecting data. The result obtained revealed that students who went beyond form four education were few, and most of the form four leavers are unemployed. They live with their parents, and are engaged in petty businesses such as 'bodaboda', 'mama ntilie', 'machinga' and subsistence farming among other things. Also, the study shows that there is no difference among those who passed through secondary schools and those who did not in terms of economic development. The study concluded that there is a small positive contribution of secondary education towards economic growth. The current study has looked at the contribution in Ngara District. For education to stimulate social and economic changes it must strive to provide the knowledge, skills, values and attitudes that arouse learners to contribute to economic development. Generally, economic growth must be incorporated into education and education must be incorporated into economic development.

\section{Relationship between Secondary Education and Social Economic Growth}

Garces (2011) conducted an empirical study in Chile which explored the different aspects of the relationship between education as one of the main components of human capital and economic productivity. The study looked on the role of education as a contributing factor of economic development. The result obtained from the empirical study done by Garces shows that the widespread consensus that population growth is detrimental to economic growth. The study concludes that there is a great relation among the increase in population and the productivity. However, Garces in his Study conducted only empirical study, and the findings rely only in the secondary data which led to lack of reliable information. The current study will focus on both primary and secondary data to obtain information which will be more reliable.

Nowak and Dahal, (2016) conducted a study on the contribution of education to economic growth in Nepal. The study investigated on the long run relationship between education and economic growth in Nepal between 1995 and 2013 through application of Johansen Integration 
technique and Ordinary Least Squares. The result showed that secondary and higher education contributes significantly to the real GDP Per Capita in Nepal. Also, the study showed a less statistically significant of the result in the influence of elementary education in economic growth. Similarly, the results obtained in the Study through Cointegration technique showed the existence of long run relationship in education and real GDP Per Capita. The study recommends making serious efforts for proper utilization of primary education level to ensure achievement of sustainable development growth.

Williams (2014), conducted a study on education and economic development: "An untapped alliance". This is a case study of the Greater Hattiesburg Area of Mississippi which seeks to explore and to begin to understand how to better the relationship between education and economic development. The study used interview method to obtain data, these data were then sorted theme by theme so as to conclude how education and economic development work together. The result of the study showed that there is a definite connection between education and economic development. Education is used as a tool for economic development, and there are challenges to establishment of the relationship between education and economic development. The researcher utilized the Grounded Theory method to guide the data collection and data analysis process.

Salgür (2013) conducted a research in the importance of education in economic growth. The main purpose of the study was to examine the relationship between education and the economic growth of a country. The study shows that investment in education is a vital part of a country's economic growth since it is very difficult for a country to accomplish a successful economic progress if it does not invest much in the education. The study concluded that education is one of the most important factors for the economic and social developments of a society and it is also the main component of the construction of human capital.

Brempong (2010), conducted a study using a panel data from two new data sets on educational attainment to investigate the effects of education on developmental outcomes in African countries. The result from the study shows that education has a great and significant impact on country development especially in the economic sector. Also, the study showed that the development level is affected with the level of education. The researcher concluded that from primary to secondary levels of education, there is a great impact in the national economic growth than tertiary level. The researcher recommends that the result obtained from the study can be used in the policy development in most of the developing countries.

\section{Challenge Facing Secondary Education System in Social Economic Development}

Singh, (2019) conducted a study in India on the issues and challenges of Indian education system in current scenario. The study comments that education is the backbone in any country for the sustainable development. The study used secondary data from various available sources. The current study will employ both secondary and primary data sources available. The findings of the study revealed that education system in India face different challenge including the lack of facilities, lack of quality education, corruption in education and the issues of curriculum. In the similar vein, the current study will look on the challenges facing education system in Tanzania toward the contribution of socio-economic growth of Tanzania as a nation. The researcher in the study assumes that issues and challenges present in the education system which hinder the growth of the country economically can be tackled effectively if constructive actions are taken by the government and other stakeholders to resolve them.

Okorafor, (2017) conducted a study in Nigeria on the implementation and Challenges of Nigerian Educational Policy in Rural Grade 1-12 Public Schools. The study employed qualitative research approach. The current study will employ both qualitative and quantitative research approaches in the process of doing research. According to Okorafor, (2017), the study employed ethnographic educational research design. The current study will employ a convergent parallel mixed research design. The research participants were selected through purposive sampling only although the current study will use both purposive and simple random sampling technique to obtain the sample to be included in the study. The study findings reveals that among the challenge in the education system in Nigeria includes the scarcity of infrastructure and facilities at all levels and the lack qualified special teachers to handle different subjects in the curriculum. In the light of the above statement the current study aims to look on the challenges facing education in Ngara district toward the contribution in socio economic growth.

Armah (2017) did a study in Ghana on the challenges of education system. The study considered the major changes that have occurred since the late 1980's with emphasis on the pre-tertiary level of education. The findings of the study revealed that the current Ghana education system have been characterized by three fundamental challenges, namely fragmented and over loaded curriculum, unequal access to education, and weak and incoherent administrative control. However, the current study will look on the challenges which encounter Tanzania education system toward the contribution of economic growth in Ngara district.

A study conducted by Saga, (2014) in Kilolo District, Iringa Region on the challenges facing community secondary schools employed both qualitative and quantitative research approaches and the study used only questionnaire as a research instrument. The current study will employ both questionnaire and the interview. The findings of the 2014 study revealed that the main challenges that limit access to quality education are shortage of teachers, inadequate teaching and learning materials as well as school infrastructures. In the line of this statement, it was observed that the education system fails to promote economic developments due to the challenges encountered. 


\section{Gap in the literature}

Globally literature indicated that education contributes to economy growth. Most of the reviewed studies are conducted in developed countries however not so much literature is documented in developed countries such Tanzania (Kapur 2020; and Garces, 2011). Moreover, looking at the methodology in most studies, the data that were used in collecting data were through secondary sources which involve documentary analysis rather than going to the field to assess the reality. Such studies are those conducted by Kapur (2020); Armah, (2017); Singh, (2019); Brempong (2010); Salgür (2013) and Misra (2012). Most of the literatures reviewed base on one approach like Lupeja and Gubo, (2016) quantitative approach. Nevertheless some reviewed studies used pure qualitative which cannot be generalized (Okorafor, 2017). The current study focus to fill the gap by employing mixed research paradigms where quantitative and qualitative will be used in the single study. Moreover, the study will be conducted in Ngara District, a place which seems to be not much literature on the mentioned topic documented hence there is a need to the current study so as to fill the existing gap.

\section{RESEARCH METHODOLOGY}

The study was used a mixed-method approach due to its strength in gathering data. A mixed research refers to the research approach which integrates the element of both qualitative and quantitative (Almalki, 2016). According to Hanson et al (2005) mixed method is the collection and analysis of both qualitative and quantitative data in a single study in which the data are collected concurrently and given priority which involves integration of data at one or more stages in the process of research. This study was employing a convergent parallel mixed approach design. The study used this research design to enable the researcher to collect satisfactory information from the respondent efficiently. The study used this design because the researcher was wants to gather both qualitative and quantitative information from respondents.

The researcher was going to the field to collect data once and analyse them separately through merging them at the end of the processes of their collection

\section{Sampling Procedures}

This study employed both probability and non-probability sampling and the sample size of this study is 113 .

\section{Data analysis procedures}

Data analysis deals with organization and presentation of the collected data (Oso and Onen 2016). This study employed both quantitative and qualitative techniques of data analysis.

The quantitative data was analyzed through Statistical Package for Social Sciences (SPSS) version 20 software and analyzed and presented through descriptive methods which provide numerical and graphical procedures to summarize data in good and clear way, (Kumar, 2011). Therefore, in the current study, data that was collected through questionnaires was being analyzed by using SPSS version 20.

Data collected through the interviews was analyzed based on themes and narrative analysis and be transcribed to get the real meaning of the study.

\section{DATA ANALYSIS AND DISCUSSION OF THE FINDINGS}

The finding obtained from the field accordance with the research objectives. In this chapter data were presented through two types of data such as Quantitative data were presented by using tables and charts and qualitative data information was presented through explanations using quotations.

\section{Contribution of Education Achieved in Secondary School Graduates on Economic Growth}

The contribution of secondary achieved in secondary school graduates on economic growth is very important. In order to explore this, the researcher used questionnaires to develop four items concerning the objectives, where four Likert scales were administered to the participants through the opinion that were given which were: strongly agree, agree, undecided, disagree and strongly disagree.

Table 1 indicates that 65 percent of the participants disagreed that lack of good secondary education has negatively influence in economic growth while 5 percentages are undecided position. Likewise, 30 percent of respondents agreed that the lack of good secondary education has negatively influence in economic growth. This means in Ngara district there is no good secondary education that why the contribution of economic growth is very slow

Furthermore, Table 1 reveals that 20 percentages disagreed that no country can succeed in sustainable economic development without educating her human capital, 10 percentages are undecided about no country can succeed in sustainable economic development without educated human capital. However, 70 percent of respondents agreed the statement equal to 14 respondents agreed. We see many responded believe in order to successful in any country provide proper education. This statement is similar with others scholars like Flora (2019), UNESCO (2017) and Chanksenlian et al. (2020) they agree that any development in country depends on provision of education for their peoples

Additionally, Table 1 shows 25 percentages of responded strongly agreed that quality secondary education contributes to sustainable economic growth and 15 percentages undecided the statement that quality secondary education contributes to sustainable economic growth. However, 60 percent equal to 12 respondents disagreed. This shows how quality secondary education is very important to the growth of economic to the society. This result corresponding with Kapur (2020) findings 
Table 1. Levels and contribution of education in economic development

\begin{tabular}{|c|c|c|c|c|c|c|c|c|c|c|}
\hline \multirow[t]{2}{*}{ Statement } & \multicolumn{2}{|c|}{1} & \multicolumn{2}{|c|}{2} & \multicolumn{2}{|c|}{3} & \multicolumn{2}{|c|}{4} & \multicolumn{2}{|r|}{5} \\
\hline & $\mathbf{F}$ & $\mathbf{P}$ & $\mathbf{F}$ & $\mathbf{P}$ & $\mathbf{F}$ & $\mathbf{P}$ & $\mathbf{F}$ & $\mathbf{P}$ & $\mathbf{F}$ & $\mathbf{P}$ \\
\hline $\begin{array}{l}\text { Lack of good secondary education has negatively } \\
\text { influence in economic growth }\end{array}$ & 2 & $(10.0)$ & 4 & $(20.0)$ & 1 & $(5.0)$ & 7 & $(35.0)$ & 6 & $(30.0)$ \\
\hline $\begin{array}{l}\text { No country can succeed in sustainable economic } \\
\text { development without educated human capital }\end{array}$ & 3 & $(15.0)$ & 1 & $(5.0)$ & 2 & (10) & 7 & $(35.0)$ & 7 & $(35.0)$ \\
\hline $\begin{array}{l}\text { Quality secondary education contributes to } \\
\text { sustainable economic growth }\end{array}$ & 7 & $(35.0)$ & 5 & $(25.0)$ & 3 & (15) & 3 & (15.0) & 2 & $(10.0)$ \\
\hline $\begin{array}{l}\text { Most of secondary school leaver lived with their } \\
\text { parents and engage in small business like } \\
\text { bodaboda }\end{array}$ & 6 & $(30.0)$ & 8 & $(40.0)$ & 2 & $(10)$ & 2 & $(10.0)$ & 2 & $(10.0)$ \\
\hline
\end{tabular}

Key: 1-Strongly Disagree; 2-Disagree; 3-Neutral; 4-Agree; 5-Strongly Agree; F-Frequency; P-Percentage

Source: Field Data (2021).

Table 2. Knowledge acquired in secondary schools contribute to economic growth

\begin{tabular}{|c|c|c|c|c|}
\hline \multirow[b]{2}{*}{ Statement } & \multirow{2}{*}{$\begin{array}{c}\mathrm{N}=81 \\
\text { Frequency }\end{array}$} & \multicolumn{2}{|r|}{$\mathrm{N}=\mathbf{2 0}$} & \multirow[b]{2}{*}{ Percent } \\
\hline & & Percent & Frequency & \\
\hline $\begin{array}{l}\text { Knowledge acquired does not influence economic } \\
\text { growth }\end{array}$ & 45 & 55.6 & 10 & 50 \\
\hline $\begin{array}{l}\text { Knowledge acquired cannot contribute to the sustainable } \\
\text { economic development }\end{array}$ & 36 & 44.4 & 10 & 50 \\
\hline Total & 81 & 100.0 & 20 & 100 \\
\hline
\end{tabular}

Field Data $(2021$

which shows that secondary education contributes to the economic development since it enables the students to acquire knowledge and skill in promoting economic growth. For field area in Ngara its does not reality because there is small contribution of secondary education.

Furthermore, in Table 1 indicates that 80 percentages agreed to the statements that most secondary school leaver lived with their parents and engaged in small business like bodaboda and only 10 percentages are undecided about most of secondary school leaver lived with their parents and engaged in small business like bodaboda. However, 10 percent of respondents disagreed that most of secondary school leavers lived with their parents and engaged in small business like bodaboda. Dary education due to the poor education provided. They live with their parents, and are engaged in petty businesses. In Ngara district most graduates are unemployed and they engage in small business-like agricultural activities. This shows how secondary education does not enable them to have skills for improvement of standard of life and economic growth.

In relation to the research objective one, the respondents were given the chance to reveal how knowledge acquired in secondary schools contributes to economic growth. The participants were furthermore required to show how knowledge acquired in secondary schools contributes to economic growth. The respondent answers are categorized in two groups as shown in the Table 2 above;

Table 2 above indicates that 55.6 percentages of student's and 50 percentages of teachers respondents agreed that the knowledge acquired in secondary education cannot contribute to the economic growth also 44.4 percentage of student responded and 50 percentage of teachers said that knowledge acquired does not contribute to the sustainable economic development. This is an indicator that knowledge acquired in secondary schools in Ngara District can hardly give positive impacts to economic development in poverty alleviation and the growth of economics to the people concerned. This makes it very difficult to make any step of development if there is no good environment which promotes the economic growth.

In order to obtain in-depth information concerning the contribution of education achieved in secondary school graduates on economic growth. The researcher conducted the interview with Heads of school, graduate youth, parents and ward executive officers. The findings are presented;

From the findings, it was reported that majority of the school heads who participated in this study said that secondary education does not ensure economic growth of an individual. Speaking about how secondary education didn't ensure economic growth, one of the heads of school has this to say:

When someone gets secondary education, they can hardly be in a position to increase productivity which finally might ensure economic growth among individual. Ngara District secondary school graduates barely grow economically because the education obtained offers little skills for job securing." (Interviewee response, HoS1, 2021).

The quotation above indicates that some of heads of school believed that secondary education is important for improving the economic while in most of graduate did not 
Table 3. Findings of Teachers Response on the Relationship between Secondary Education and Economic growth (n=20).

\begin{tabular}{|c|c|c|c|c|c|c|c|c|c|c|}
\hline \multirow[t]{2}{*}{ Statement } & \multicolumn{2}{|r|}{1} & \multicolumn{2}{|c|}{2} & \multicolumn{2}{|c|}{3} & \multicolumn{2}{|c|}{4} & \multicolumn{2}{|c|}{5} \\
\hline & $\mathbf{F}$ & $\mathbf{P}$ & $\mathbf{F}$ & $\mathbf{P}$ & $\mathbf{F}$ & $\mathbf{P}$ & $\mathbf{F}$ & $\mathbf{P}$ & $\mathbf{F}$ & $\mathbf{P}$ \\
\hline $\begin{array}{l}\text { Secondary education prepare youth for the future } \\
\text { labor market }\end{array}$ & 2 & 10.0 & 4 & 20.0 & 2 & 10.0 & 6 & 30 & 6 & 30.0 \\
\hline $\begin{array}{l}\text { Secondary education is directly proportional to the } \\
\text { increase in economic growth }\end{array}$ & 3 & 15.0 & 3 & 15.0 & 1 & 5.0 & 7 & 35.0 & 6 & 30.0 \\
\hline Secondary education ensure poverty alleviation & 3 & 15.0 & 3 & 15.0 & 1 & 5.0 & 7 & 35.0 & 6 & 30.0 \\
\hline $\begin{array}{l}\text { Secondary education influence positively the change } \\
\text { in economic aspect }\end{array}$ & 3 & 15.0 & 3 & 15.0 & 1 & 5.0 & 5 & 25.0 & 8 & 40.0 \\
\hline
\end{tabular}

Key: 1-Strongly Agree; 2-Agree; 3-Neutral; 4-Disagree; 5-Strongly Disagree; F-Frequency; P-Percentage

Source: Field Data (2021).

grow economically. They are still poor although they have already received secondary education.

Likewise, another head of school explained that;

The secondary education provided in school does not give the skills and knowledge on how to enlighten learners on how to grow economically. We can see in our society their fate and how it is difficult to differentiate secondary graduates and non-secondary graduates on terms of contribution on economic growth because all of them they done similarly economic activities. (Interviewee response, HoS2, 2021).

This is contrary to the explanation provided by a third head of school who commented that the secondary education provided contributes to the economic growth among the secondary school graduates (Interviewee response, HoS3, 2021). Through this explanation we can see any economic depended on the provision of education. The HoS said that any economic activities in the society must depend on the presence of educated people who surrounds them. In regard to this one parents' respondent has this to say'

"Some of our children understand how to adapt new things and also to modify other things. This is due to the education provided in secondary school is barely for selfreliance. This shows that they benefit and make them to participate to the economic growth although most of them are still depending on us for everything to run their daily lives." (Interviewee response, 2021)

This quotation shows how secondary education is important for economic growth although many graduates still depend on their parents to support their up keep.

\section{The Relationship between Secondary Education and Economic growth}

Table 2 shows that 2 teachers equal to 10 percent of teachers strongly agreed that secondary education prepare youth for the future labor market, likewise 4 teacher's equal 20 percent of teachers agreed that secondary education prepare youth for the future labor market. However, 2 teachers equal to 10 percent of teachers were neutral. Despite higher percent of agreement 30 percent of teachers equal to 6 teachers strongly disagreed similar with
30 percentages 6 teachers disagreed. This implies that in Ngara district secondary education does not prepare youth for the future labor market.

Table 3 shows that 30 percent of teachers equal to 6 teachers strongly disagreed likewise 7 teachers equal to 35 percent of teachers disagreed that secondary education is directly proportional to the increase in economic growth. However, 3 teachers equal to 15 percent of teachers strongly agreed similar 3 teachers agreed that secondary education is directly proportional to the increase in economic growth. Teacher was neutral equal to 5 percent of teacher. This implies that in Ngara district secondary education is indirectly proportional to the increase in economic growth. The findings contrary with Brempong (2010) findings which explain that education has great impact in economic development of the country likewise Williams (2014) comment that there is definite connection between education and economic development. Generally, education is a vital organ for the economic development.

Also, in the statement that secondary educations ensure poverty alleviation 3 teachers equal to 15 percent of teachers strongly agreed likewise 15 percent of teachers agreed. Despite the agreement percentage 30 percent of teachers equal to 6 teachers strongly disagreed likewise 35 percent of teachers disagreed that secondary educations ensure poverty alleviation. However, 1 teacher equal to 5 percent of teacher was neutral. The majority of the respondents disagreed that secondary education ensures poverty alleviation this implies that in Ngara district education acquired in secondary school does not alleviate poverty this shows that there is no good relation among secondary education and economic growth. The findings opposing Nowak and Dahal, (2016) findings which show that the investment in education will raise growth per capital income hence will reduce poverty.

Furthermore, in determination of a relationship among secondary education and economic growth the research asked teacher to rate the level of agreement on the statement that secondary education influence positively the change in economic aspect. 40 percent of teachers equal to 8 teachers strongly disagreed that secondary education influence positively the change in economic aspect likewise 25 percent of teachers equal to 5 teachers disagreed. 
Despite higher percent of disagreement 15 percent of teachers equal to 3 teachers strongly agreed and agreed in the fact that secondary education influences positively the change in economic aspect. And only 1 teacher is Neutral.

Furthermore, the finding obtained through questionnaire corresponding with the information obtained through interview with the head of schools, ward executive officer, parents and youth graduates.

A ward executive officer in the first ward explains that in secondary education provided in school does not prepare youth for the future labor market this occur in the fact that the education provided do not correlate the knowledge delivered with the job opportunity available. The interviewee quoted that;

Education provided to our youth does not prepare them to fight to the labor market available, since youth are provided with education which prepare them for being employed though in the presence scenario labor market is not good as you compare employment opportunity available compare with the graduates" (Interviewee response, WEO1, 2021).

This quotation state about the education provided with the real situation of life is very different because they prepare youth for employment only not foe self-reliance although the labor market is very difficult.

WEO from ward B revealed that secondary education is not directly proportional to the increase in economic growth. Was said that

"You can't compare education gets in school with the real home life, because most of graduates they live poor life, their incomes still so low that it can't even afford to meet their needs, this is because what they have learned in class they do not use at home, they have only studied in theory only without being practical".

The findings show that WEO believe secondary graduates have a role to participate in economic growth but it difficult due to the kind of education provide does not enable them to be independent to fight against economic growth.

Similar with another head of third secondary school who was clarified that

In Ngara district secondary education provided to the youth does not ensure poverty alleviation, since the skill and knowledge provided does not prepare the youth to fight against poverty though it prepares them to be employed. We can see on our society we still poor even though we have educated many children in secondary school, the changes in society are not in line with the larger number of children who have completed form four or form six. (Interviewee response, HoS3, 2021).

The aim of secondary education is to ensure poverty alleviation but we fail to reach the goals because we have larger number of graduates but the rate of poverty is still the same even if every year there is big number of graduates in the society.

The findings contrary to the information provided with the fourth head of school who comment that the aim of education is to alleviate poverty hence the education provided in secondary school alleviate poverty among the youth graduates (Interviewee response, HoS4, 2021). Therefore, this shows there is no relationship exists between secondary education and economic growth among youth graduates.

Also, one of the youth graduates comment that secondary education is directly proportional to the increase in economic growth this means that secondary education is essential for the economic growth, was said that;

We get benefit through presences of secondary schools because we have opportunity to participate to the economic activities, most of those found employment have received secondary education through they went on to study more courses but they depend on presence of secondary education.

Interviewee response, Yg1, 2021).

Through this context we see that the relationship between secondary education and economic growth depends on other courses not only secondary education can be self-sufficient.

Other third youth graduates clarified that there is no relationship among secondary education and economic growth. Was state that

The education provided does not give skill and knowledge on how to ensure economic growth, we depend on fight the work which does not resemble with our studies, most of us have been in activities that we have not studied in class but we do just to make ends meet, for example you see here most of us sell second- hand clothes we have studied up to form four other form six but we have no more work to do just here in our street life to sustain life. (Interviewee response, Yg3, 2021).

\section{Challenge Facing Secondary Education System in Economic Development}

Figure 2 shows the distribution of the student's response on the challenges facing secondary education system in contributing to economic growth were 21 students equal to 25.9 percent of students mentioned shortage of physical resource as a challenge which facing secondary education system in contributing to economic growth. The findings corresponding with Okorafor, (2017) who comment that in education system the scarcity of facilities and infrastructure is a challenge thus make difficult for the system to contribute toward economic development. Likewise, Saga, (2014) comment that education system challenged with the shortage of facilities as well as infrastructure thus make it difficult for the contribution of economic growth.

From Figure 2, 45.7 percent of students equal to 37 students admitted to the curriculum challenge as a challenge facing secondary education system in contribution to economic growth. The challenge of curriculum mainly observed in the way of implementing curriculum to ensure effective achievement of competencebased curriculum. The findings corresponding with Singh, (2019) findings which explained that in the education system there is the issue of curriculum and the lack of facilities which interfere the effectiveness of education system and finally become a challenge in the contribution toward economic growth. Likewise, Armah, (2017) comment that in the issue of curriculum it's a challenge due to the overloaded curriculum thus become difficult for the 


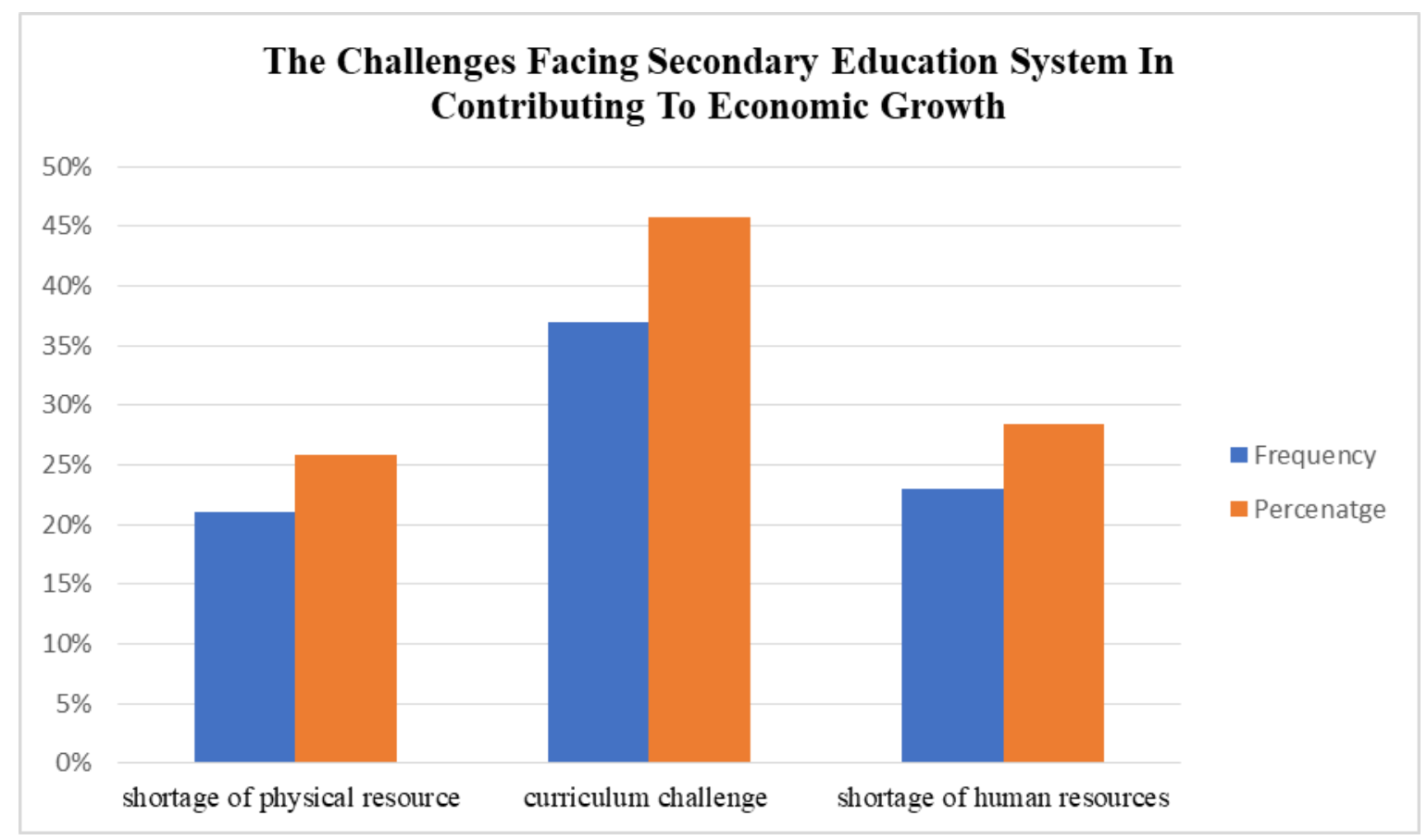

Figure 2: The challenges facing secondary education system in contributing to economic growth

Students Response ( $\mathrm{n}=81)$

Source: Field Study (2021)

system to contribute toward the economic growth. Therefore, for the education system to contribute effectively on the economic growth there should be with effective implementation of curriculum.

Figure 2 also indicates that 28.4 percent of students equal to 23 teachers mentioned shortage of human resources as a challenge facing secondary education in the contribution of economic growth. This implies that in Ngara district there is insufficient human of resource which becomes a challenge in ensuring effective provision of secondary education in Ngara district. In findings consistent with Saga (2014) which reported that the shortage of teachers in school is a challenge in education system for it to contribute toward economic development.

Figure 3 indicate the distribution of the teacher's response on the challenge facing secondary education system in contributing to economic growth. 45 percent of teachers equal to 9 teachers mentioned curriculum challenge as a challenge in education system. This means that in Ngara district most of the teachers observed that the implementation of curriculum is a challenge in education system. This consistence with Armah, (2017) findings which shows that curriculum overloaded is a great challenge in the effective implementation of curriculum. As well as Okorafor, (2017) findings which shows there is no specific teacher to handle different subject in curriculum. Thus, in curriculum challenge there is ineffective implementation of curriculum this led to ineffective contribution of economic growth.
Also, in Figure 3, 30 percent equal to 6 teachers reported shortage of human resources as a challenge in education system. This shows that in Ngara district education system challenged with the insufficient teachers thus why the education provided did not contribute to the economic growth. The findings corresponding with Saga, (2014) findings which explain that the shortage of qualified teachers is the challenge in education system in contribution toward economic growth. Generally, teachers are responsible in running education system when they are not enough, they will led to the ineffective running of education system thus will not contribute to the economic growth.

As well as in Figure 3, 25 percent equal to 5 teachers mentioned the shortage of physical resource as a challenge in education system on the contribution toward economic growth. This means that in Ngara district physical resources available are not enough in running education system, thus become a challenge in the system to contribute toward economic growth. The result supported with Singh, (2019) who comment that the lack of facilities is a challenge in running education system. Likewise, Saga, (2014) comment that the lack of teaching and learning material is a challenge in running education system. Therefore, physical resources are important in running education system when are inefficient, they led to the ineffective contribution of education system toward economic growth.

The third objective focused on challenge facing secondary education system in economic growth was 


\section{The Challenge Facing Secondary Education System In Contributing To Economic Growth Teachers}

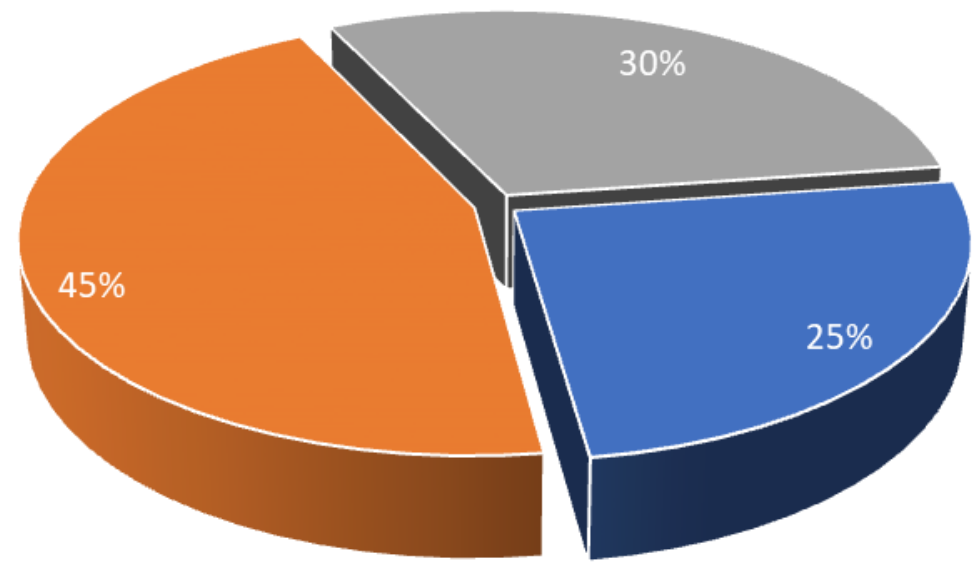

- Shortage of Physical

- Curriculum Challenge

- Shortage of Human Resorce

Figure 3: The Challenge facing secondary education system in contributing to economic growth Teachers

Response $(n=20)$

Source: Field Study, (2021)

developed. This is because it helps to know whether the research participants know the challenges facing secondary education system in economic growth. The researcher used questionnaires to develop three questions. Furthermore, the findings from the interview of this study revealed several findings as described below;

Interview with head of school 1 give a clarification that

One of the challenges that we face is shortage of teacher's especial science teachers. Most of topics are not recovered well, as the result the content is not well acquired; in this school we have two teachers for mathematics subject while we have high larger number of students (Interviewee response, HoS1, 2021),

These statements show how shortage of teachers are create negative economic growth because students did not covered well syllabus for some subjects, also the higher number of students as seem as problem due to be less ratio with the total number of teachers provided.

likewise, a head of third school comment that there are few teachers in secondary school in that sense it's a challenge in the implementation of education system and contribution toward economic growth, in this explanation the interviewee quoted that;

"Frankly speaking. We have very few teachers for instance here we have only 22 teachers and more than 800 students. The number of teachers is not proportional to the number of students. That means it's very hard for every student to get the desired content as a result when they complete their study they are not well equipped so as they can contribute well in economic growth" (Interviewee response, HoS3, 2021),.

The findings above show that lack of teacher and higher number of students caused the graduates to not able to meet the desired education content because they not well equipped so as fail to have enough skills of economic growth in Ngara district.

This is also similar to Saga, (2014) in the study revealed that the main challenges that limit access to quality education are shortage of teachers, inadequate teaching and learning materials as well as school infrastructures make our society to fail to be benefit with our education in the term of economic growth.

Also head of school in second school comment that

it is very difficult to achieve the goals of teaching because of the shortage of teachers we have, teachers are overwhelmed with work by having more period than they can afford, this makes it impossible to achieve the goal set by the government in relation to secondary education (Interviewee response, HoS2, 2021).

Similar with one of parent comment that

We see in other school teachers are insufficient compare to the number of students available. This is a challenge in 
running effectively education system hence it becomes a challenge in contribution toward economic growth because teachers fail to serve all students equally due to overcrowding. (Interviewee response, 2021).

Parent as seen teachers insufficient enable children to fail to reach secondary target education goal because due to high number of student enrollment teacher are not able to manage all of them, also its difficult for teachers to fallow private development for students to know their weakness or their strength this make many graduates to complete secondary education with insufficiency skills of economic growth.

\section{Conclusions and Recommendations}

The findings established that there is a low contribution of secondary education achieved by secondary graduates on economic growth because the rate of economic growth is very small compared to the number of people graduating from secondary each year, Based on the summary of the findings, the study concluded that there is no strong link between secondary education and economic growth because most of graduates are jobless, are not able to contribute to the increase of development, most of them are still depending for parents or guardians even if they have enough age for being independent. Furthermore, the findings of this study showed that the various challenges in secondary education led to slower economic growth in the community. The curriculum in schools does not meet the needs of the community because what a student's learning in school ends there and does not applicable in real daily life. Research recommends that in order to have contribution of secondary education in the economic growth must ensure the presence of quality education. Means education which gets in school must resemble with needs of society and it's important to make much practical during the schools better than theory only. This is for all teachers, community, other stake holders and government. Also, the researcher recommends that the government through the ministry of education should make the modification of curriculum so that what is taught in school can contribute to the needs of the society.

\section{Conflict of interests}

The authors declare that there is no conflict of interests regarding the publication of this manuscript.

\section{REFERENCES}

Abayo GG (2017). Examining the Contribution of Ward Secondary Schools into Form Four Leavers' SocioEconomic Development in Kilindi District Council. (Master dissertation, Open University of Tanzania). Retrieved from http://repository.out.ac.tz/2149/1

Akaro BB, Mkulu DG (2020). Role of universities in realization of industrial economy in Moshi urban, Tanzania: The case of Moshi co-cooperative university. J. Humanities and Education Development. (JHED),
2(3):208-215.

Almalki S (2016). Integrating Quantitative and Qualitative Data in Mixed Methods Research Challenges and Benefits. Canadian Center of Science and Education. J. Education and Learning, 5(3):288-296.

Armah PH (2017). Overview And Challenges of Ghana's Education System. Retrieved from https://www.academia.edu/34610399

Brempong KG (2010). Education and economic development in Africa. Department of Economics University of South Florida. East Fowler Avenue Tampa.

Chanksenlian M, Qoraboyev I, Gimranova D, (2020). Higher education contributing to local, national and global development: New Empirical and Conceptual Insights. Higher Education (2021) 81: 109-127.

Education for Sustainable Development (2017) Paris: UNESCO.http://unesdoc.unesco .org/images/ (accessed 3 February 2017).

Flora G (2019). Education and socio-economic development: significances of the 'learning region' concept. Department of Social Sciences, Faculty of Human and Social Studies, Partium Christian University, Oradea Euro regional J. Socio-Economic Analysis 2:18-27.

Garces JP (2011). "Three Essays on Education and its Impact on Economic Growth and Development". (Doctoral Dissertations. University of Connecticut) AAI3476647.

https://opencommons.uconn.edu/dissertations/AAI347 6647

Grant C (2017). The Contribution of Education to Economic Growth. K4D Helpdesk Report. Brighton, UK: Institute of Development Studies.

Hanson, William E, Creswell, John W, Plano C, Vicki L, Petska KS, Creswell J. David, "Mixed Methods Research Designs in Counseling Psychology" (2005). Faculty Publications, Department of Psychology, 373. Int. J. Econ. Management Systems, 4 (2): 140-156

Kapur R (2020). Secondary Education and Socio-Economic Growth. Retrieved from https://www.researchgate.net/publication/341900769_ Secondary_Education_and_Socio-Economic_Growth

Kumar R (2011) Research Methodology: A Step-by-Step Guide for Beginners ( $3^{\text {rd }}$ ed). New Delhi: Sage Publications.

Lupeja TK, Gubo Q (2016). Secondary Education Attainment and Social Economic Transformation in Rural Tanzania: Observations from Livelihood Strategies of Primary and Secondary Education Graduates in Mvomero District. J. Education and Practice, 7(32):144-150.

Misra (2012). Contribution of education in the socioeconomic development. An empirical Study. LUMEN International Conference Book, Iasi, Romania. Retrieved from

https://www.researchgate.net/publication/269692018

Mkulu DG, Paschal MJ (2020). The contribution of private sector in the provision of higher education in Tanzania: Growth and Challenges. J. Humanities and Education Development. (JHED), 2(3):155-169.

Mkulu DG (2020) Role of holistic Education in empowering university students for industrial development in 
Tanzania. J. Humanities and Education Development. (JHED), 2(3):177-190.

Nowak AZ, Dahal G (2016). The contribution of education to economic growth: Evidence from Nepal. International J. Economic Sciences 2(2):21- 41.

Okorafor F (2017). The Implementation and Challenges of Nigerian Educational policy in Rural Grade 1-12 Public Schools. (Master dissertation, University of Northern British Columbia). Retrieved from https://www.academia.edu/37316487

Oso WY, Onen D (2016) Writing research proposal and report; handbook for beginning researchers. Nairobi; Kenya

Paschal MJ, Mkulu DG (2020). Teacher- Students' Relationship and Students 'Academic Performance in Public Secondary Schools in Magu District, Tanzania. Journal of Research in Education and Society, 11(1):2023.

Paschal MJ, Nyoni TT, Mkulu DG (2020). The Role of Cooperative Learning in Attaining Inclusive Learning in the Classroom, Creativity and Innovation in Secondary Schools in Mwanza Region - Tanzania. International J. English Literature and Social Sciences, (IJELS), 5(2).

Saga MW (2014). Access And Quality Challenges Facing Community Secondary Schools: A Case of Kilolo District Iringa, Tanzania. (Master dissertation, The Open University of Tanzania)

Sakmurzaeva N (2019). The Role of Education in Economic Development: A Comparison of South Korea and Kyrgyzstan Kyrgyzstan-Turkey Manas University, Kyrgyzstan.
Salgü SA (2013). The importance of education in economic growth. Euromentor J. IV (4), 50-57.

Singh R (2019). Issues \& Challenges of Indian Education System in Current Scenario. International J. for Innovative Engineering and Management Research 8(2):2456 5083.

UNESCO (2017). UNESCO Global Action Programme on Education for Sustainable development: Information Folder. Paris, UNESCO.

Williams SE (2014). Education and Economic Development: An Untapped Alliance. Honors Theses. 202. Retrieved from https://aquila.usm.edu/honors_theses/202 